\title{
Exploring Factors That Affect Usefulness, Ease Of Use, Trust, And Purchase Intention In The Online Environment
}

\author{
Yoon C. Cho, KDI School of Public Policy and Management, Korea
} Esen Sagynov, Naver Corporation, Korea

\begin{abstract}
Various studies have examined the effects of factors on online attitudes and behavior. By applying the Technology Acceptance Model, this study is focused on investigating factors that affect customers' online purchasing behavior. In particular, this study examines i) effects of such factors as product information, price, convenience, and perceived product or service quality on perceived usefulness; ii) effects of convenience, perceived product or service quality, and desire to shop without a salesperson on perceived ease of use; iii) effects of perceived ease of use on perceived usefulness; iv) effects of perceived ease of use and usefulness on intentions to shop online; and v) effects of trust on purchase intentions.

The data collected online and offline were analyzed using factor and regression analysis, and structural equation modeling. The results of this study indicate that perceived usefulness, perceived ease of use, and trust had a statistically significant effect on behavioral intention to shop on the Internet.
\end{abstract}

Keywords: Product Information; Price; Convenience; Product and Service Quality; Salesperson; Perceived Usefulness; Perceived Ease of Use; Trust; Intention to Purchase

\section{INTRODUCTION}

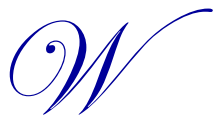

ith the continuing growth of the Internet, various researchers have examined such differential effects as perception, attitude, and behavioral changes on the online, so-called virtualized and computer-mediated environment (Hoffman and Novak, 1996) compared to the offline environment, called the marketplace. By considering technology adoption and customers' or users' behavioral changes in the virtualized environment (Hoffman and Novak, 1996), previous studies examined diverse effects, such as information searching and purchasing behavior, social networking systems, product categories, prices, and personalized (i.e., customized or individualized) services in diverse sectors from online banking to e-government services. Previous studies examined such factors as perceived risk and benefit influencing the adoption of Internet banking (Lee, 2008); service-oriented technology and management (Demirkan et al., 2008); effects of consumer perceptions of brand experiences, brand familiarity, satisfaction;, and trust on the Web (Ha and Perks, 2005); trustworthiness of advice about seller agents in e-marketplaces (Zhang and Cohen, 2008); and changes in consumer behavior by applying consumer informedness and an understanding of consumers' pursuit of products (Clemons and Gao, 2007). Studies also investigated applications of 2Is (i.e., interactivity and individualization) known as key factors in the success of e-business. Macias (2003) discussed how interactivity and individual difference variables affect the comprehensive of interactive advertising websites and acceptance of online customization (i.e., individualization) in e-retailing, defined by Srinivasan, Anderson, and Ponnavolu (2002, cited in Cho and Fiorito, 2009) as the ability of an e-retailer to tailor products, services, and the transactional environment to individual customers, and the impact of online agents focusing on interactivity (Kohler, Rohm, Ruyter, and Wetzels, 2011). Despite these and other studies, other areas remain to be explored, for example, in public sector and developing countries that also need application of e-business models. 
Purchasing a product in the online environment is an increasingly common practice for consumers worldwide, especially in those countries with well-developed marketing infrastructures (Kau, Tang, \& Ghose, 2003). Customers in all age groups use the Internet as a substitute channel for acquiring goods and services. According to the Consumer Choice Survey conducted by Princeton Survey Research Associates International (Horrigan, 2008), almost all Internet users (93\%) have, at one time or another, done something related to ecommerce. The developmental stage of a particular country might be determined by the existence of a fully functioning Internet marketplace - a virtualized environment in which a person can find and buy almost any product, including fashion goods and food, for a fixed price that is less than or equal to that at an ordinary shopping center. Existence of online payment system might indicate how well the banking sector is developed in the country. However, for several reasons, online shopping websites encountered problems, even in developed countries, two decades ago. First, the banking and transaction system might not successfully or conveniently provide the electronic means for money transfer. Second, the countrywide delivery system was unsatisfactory because of time, cost, and unreliability. Third, the people themselves were not always ready for such innovations. Other reasons include some minorities did not have the necessary computer and Internet skills and customers simply did not have easy Internet access. These problems are still severe in countries where the Internet is in a developing stage. To send a specific item, a person generally needs to be able to reach the nearest post office, which requires a transportation fee as well as travelling time. In addition, the delivery service may be a high price, discouraging the use of postal service and possibly significantly affecting the acceptance of online shopping.

In light of these considerations, the purpose of this study is to explore the factors that influence behavioral intentions in a certain context to shop on the Internet. The core constructs of the framework are adapted from the well-known Technology Acceptance Model (TAM) by Davis (1989), one of the most influential extensions of Ajzen and Fishbein's Theory of Reasoned Action (TRA) and has been proven to be suitable as a theoretical foundation for the adoption of e-commerce by numerous researchers (Chen, Gillenson, \& Sherrel, 2002; Moon \& Kim, 2001; Lederer, Maupin, Sena, \& Zhuang, 2000; Agarwal \& Jayesh, 1999; Gefen \& Detmar, 1997; Adams, 1992). This study addresses the main research question, "What drives consumers to shop online?" In particular, this study examines i) the effects of factors such as product information, price, convenience, and perceived product or service quality on perceived usefulness; ii) the effects of convenience, perceived product or service quality, and desire to shop without a salesperson on perceived ease of use; iii) the effects of perceived ease of use on perceived usefulness; iv) the effects of perceived ease of use and usefulness on intentions to shop online; and v) the effects of trust on purchase intentions to shop online.

\section{LITERATURE REVIEW}

The contemporary market encompasses a wide range of businesses and services. Some are closely involved in electronic commerce, which is defined as "purchases and sales of goods and services transacted over the Internet" (Choo \& Bontis, 2002). Ever since the presence of the Internet, various studies have examined changed customers' attitudes and behavior in the online environment. Previous studies found that consumers' shopping behaviors in online stores may be different from those in traditional retail stores (Alba et al., 1997; Winer et al., 1997). The online environment has been referred to as a virtualized, marketspace, and computer-mediated environment (Hoffman and Novak, 1996), with no physical salesperson but web-based interaction and services based on advanced technology and systems. Strategies have been applied online to overcome the limitations compared to offline shopping experiences, such as adoption of online agents, personalization (i.e., individualization, customization), interactivity, recommender systems, and payment and e-transfer systems, such as a subliminal channel (Chen and Liu, 2009). Those advanced systems help reduce customers' consideration sets, facilitating better decision making, and making the decision-making process more efficient (Peterson and Merino, 2003; Widing and Talarzyk, 1993).

Attitudes and behavioral intentions toward the online environment have been widely supported by the Technology Acceptance Model (TAM) (Davis, 1989). Earlier studies of e-commerce considered how customers adopt the technology in a computer-mediated environment. To change perceptions in e-commerce, studies addressed customers' willingness to change attitudes and behaviors by focusing on ease of use and usefulness (Davis, 1989) key variables in the TAM. Technology acceptance has been a prominent research stream in information systems for over two decades, with the TAM and the primary constructs of perceived ease of use (EOU), perceived usefulness 
(U), and behavioral intention (BI) (Davis, 1989; Davis, Bagozzi, and Warshaw, 1989; cited in Hess, McNab, and Basoglu, 2014). The first determinant is perceived usefulness, defined as the individual's perception that using the new technology will enhance or improve her or his performance (Davis, 1989; Davis, Bagozzi, and Warshaw, 1989). The second determinant - perceived ease of use - refers to the extent to which a person believes that using the new technology will be free of effort (Davis, 1989; Davis, Bagozzi, and Warshaw, 1989). While perceived usefulness refers to consumers' perceptions regarding the outcome of the experience, perceived ease of use refers to their perceptions regarding the process leading to the final outcome (Monsuwe, Dellaert, \& Ruyter, 2004). The TAM has been tested and validated by numerous researchers and shown to be suitable as a theoretical foundation for the adoption of e-commerce (Chen, Gillenson, \& Sherrel, 2002; Moon \& Kim, 2001; Lederer, Maupin, Sena, \& Zhuang, 2000; Agarwal \& Jayesh, 1999; Gefen \& Detmar, 1997; Adams, 1992). In addition, researchers agree it is appropriate to draw analogies between online shopping and the components of the TAM because the model has been widely used in the study of online user behavior and they explain why online users accept or reject websites and how their internal beliefs and attitudes affect their usage behavior (Davis, Bagozzi, \& Warshaw, 1989; Baroudi, Olson, Ives, \& Davis, 1986). The TAM, which addresses behavioral intention to use a new technology determined by the individual's attitude toward the technology, has been applied to various situations, including banking, information services, payment services, and so on. The TAM also has been to investigate user acceptance of information technology (Venkatesh, Morris, Davis, and Davis, 2003), customer adoption of mobile payment services (Thakur 2013), user acceptance of information systems (Hong, Thong, Chasalow, and Dhillon, 2011), information system adoption and acceptance (AlShibly, 2014), consumer acceptance and use of information technology (Venkatesh, Thong, and $\mathrm{Xu}, 2012$ ), and consumers' acceptance and use of information and communications technology (Alwahaishi and Snasel, 2013). Studies also used the TAM to explore user attitude and intention (Zhu, Lin, and Hsu, 2012) and behavioral intentions (Hess, McNab, and Basoglu, 2014).

Besides the functional and utilitarian dimensions of such consumer perceptions as perceived usefulness and perceived ease of use, a more recent addition to the TAM considers an emotional and hedonic dimension of perception - enjoyment (Menon \& Kahn, 2002; Childers, Carr, Peck, \& Carson, 2001). The enjoyment construct refers to the extent to which the activity of using the new technology is perceived to provide reinforcement in its own right, apart from any performance consequences that may be anticipated. Childers et al. (2001) supported the idea of the dual characterization of consumers' motivations, suggested by Hirschman and Holbrook (1982), which described consumers as either problem-solvers or seekers of fun, fantasy, arousal, sensory stimulation, and enjoyment. For problem-solvers, shopping is considered to be an errand or work, and they shop online only to acquire a specific product or service (Babin, Darden, \& Griffin, 1994). Their main concern is to purchase products in an efficient and timely manner with the least effort. In contrast, the second category of consumers perceives online shopping as enjoyment, looking for the potential entertainment resulting from the fun and play arising from the Internet shopping experience. They appreciate the online shopping experience for its own sake, besides any other consequence, such as an online purchase that may result (Holbrook, 1994). This study explores that the effects of perceived usefulness, perceived ease of use and other constructs ultimately affect consumers' intentions to shop on the Internet.

Theoretically, technology acceptance and use of technology are supported by the unified theory of acceptance and use of technology, which has served as a baseline model and has been applied to the study of a variety of technologies (Venkatesh, Morris, Davis, and Davis, 2003; Venkatesh, Thong, and Xu, 2012). Technology acceptance and attitudes toward behavior have been supported by various models and theories. The Theory of Reasoned Action (TRA), drawn from social psychology (Fishbein and Ajzen, 1975) and indicating an individual's performance of a given behavior, is primarily determined by his or her intention to perform that behavior (Ajzen \& Fishbein, 1980; Fishbein \& Ajzen, 1975) and is applied to individual acceptance of technology (Davis, Bagozzi, \& Warshaw, 1989; Venkatesh, Morris, Davis, and Davis, 2003). The Theory of planned behavior (TPB) extended the TRA by adding the construct of perceived behavioral control (Ajzen 1991, Taylor and Todd 1995) and the innovation diffusion theory (IDT) grounded sociology (Rogers 1995) with a variety of innovations (Tornatzky and Klein 1982). Uses and gratification theory addresses motivation and satisfaction for using a communication media or technology (Katz, Blumler, and Gurevitch 1973) and also supports technology acceptance and behavior. 


\section{HYPOTHESES DEVELOPMENT}

The proposed model for this study was modified from the TAM (Davis, 1989; Davis, Bagozzi, and Warshaw, 1989). As shown in Figure 1, this study examined i) the effects of such factors as product information, price, convenience, and perceived product or service quality on perceived usefulness; ii) the effects of convenience, perceived product or service quality, and desire to shop without a salesperson on perceived ease of use; iii) the effects of perceived ease of use on perceived usefulness; iv) the effects of perceived ease of use and usefulness on intentions to shop online; and v) the effects of trust on intention to shop online.

\subsection{Effects of Perceived Usefulness}

Perceived usefulness is defined as the individual's perception that using the new technology will enhance or improve his or her performance (Davis, 1989, 1993). Applying this definition to the context of online shopping, usefulness refers to the degree to which consumers believe using the Internet as a medium will improve their performance or productivity, thus enhancing the outcome of their shopping experience (Monsuwe, Dellaert, \& Ruyter, 2004). Perceived usefulness is related to the outcome of the shopping experience (Monsuwe et al., 2004). Detailed information, accessibility, and speed, as well as availability of inexpensive and convenient purchases, have often been mentioned as the main benefits of online shopping (Khalifa \& Limayem, 2003; Shim, Shin, \& Nottingham, 2002). For experienced Internet users who are busy during normal shopping hours, the accessibility and speed of shopping may be truly useful features.

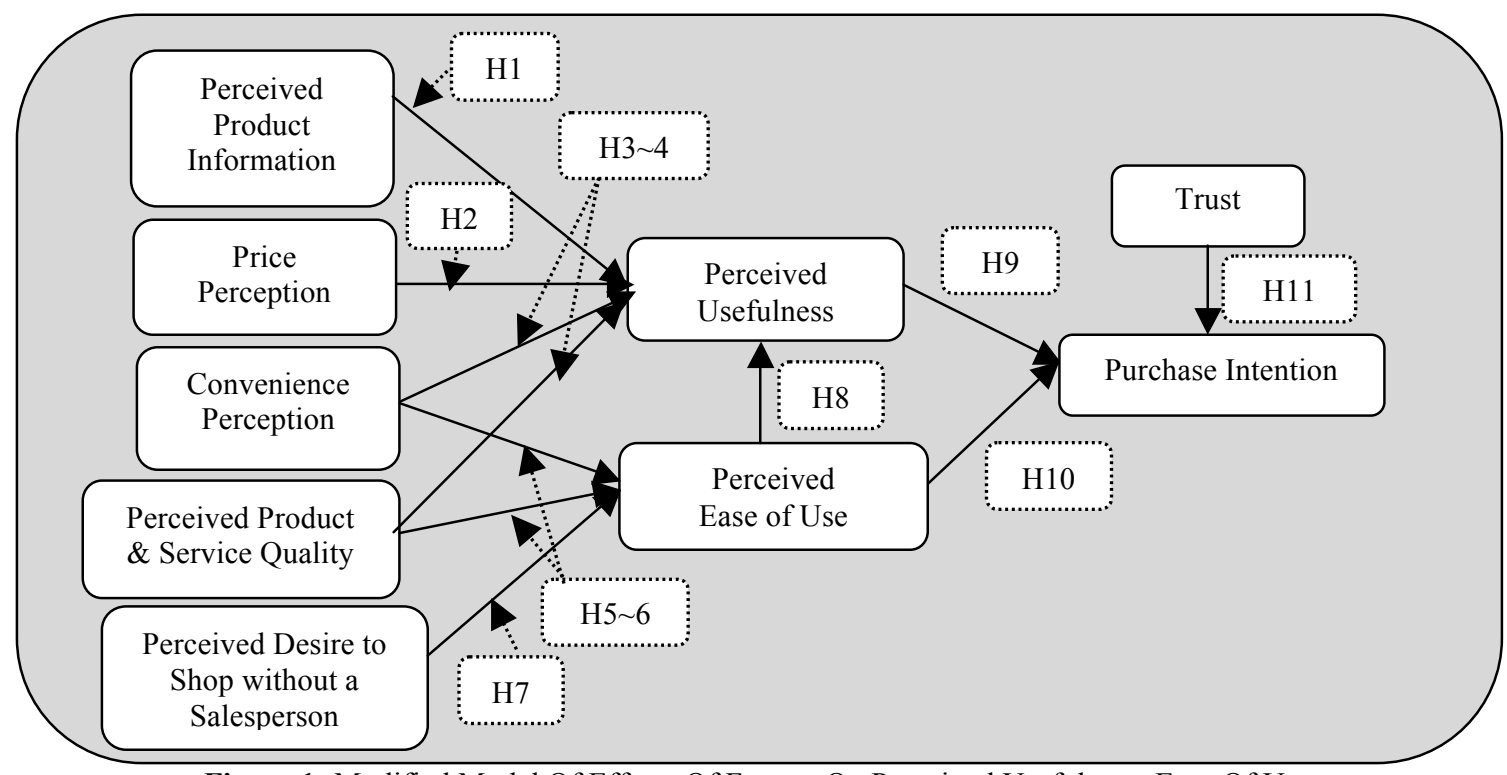

Figure 1: Modified Model Of Effects Of Factors On Perceived Usefulness, Ease Of Use,

Trust, And Intention To Purchase (Modified From Davis 1989)

\subsubsection{Effects Of Perceived Product Information On Perceived Usefulness}

In this study, product information is taken as a separate independent variable to analyze its influence on perceived usefulness. One of the major differences between traditional and online stores is the amount of information provided during shopping activities. In the offline environment, consumers are often exposed to promotions offered by diverse media and salesperson. Many merchants prioritize individual sales over customers' loyalty; that is, a salesperson tries very hard to sell the product, particularly in personal selling, stressing product features such as the quality and ease of use of the product. In the online environment, users can browse a great amount of information that provides detailed characteristics of products and services. By applying advanced systems, such as a recommender system, a collaborative filtering system, and a feedback system, online customers can easily obtain detailed reviews and information about desired items. Online customers can also take advantage of 
publicly available complaint management web portals, such as Complaints.com, bbbonline.org (Better Business Bureau Online), Cnet.com, and eComplaints.com, which provide customers' feedback, their opinions, comments, and product ratings.

Further, in the online environment, how customers perceive products online depends on how easily the product quality can be determined because customers cannot see, touch, feel, or smell the products (Figueiredo, 2000). Customers rely more on product information for products, particularly in terms of the look-and-feel of goods, so they can consider different levels of sensory attributes in terms of the look-and-feel aspect (Figueiredo, 2000; Jung, Cho, \& Lee, 2014) because they cannot physically touch the products online. Because of the limitation of the computer-mediated environment, online customers rely more on detailed product information, which has become an advantage of online over offline shopping and easy-to-get useful product information. Customers also use the Web before going into the physical store to find good deals and promotions, compare prices, or find information about sales and coupons for physical locations. Therefore, the detailed product information and a visual guide in online shopping stores, as well as independent choices available, would positively affect consumers' behavioral intentions to shop online through perceived usefulness. Consumers' purchase decision making is determined by how the information provided from e-businesses is useful. Therefore, this study hypothesized that detailed product information available online affects perceived usefulness.

H1: Detailed product information provided online has a positive effect on perceived usefulness.

\subsubsection{Effects Of Price Perception On Perceived Usefulness}

Price is unquestionably one of the most important marketplace cues (Lichtenstein, Ridgway, and Netemeyer, 1993) and may be said to have both attracting and repelling characteristics (Monroe, 1979; cited in Johnson and Kellaris, 1988). Lichtenstein, Ridgway, and Netemeyer (1993) stated that if the price cue is indeed a complex stimulus, finer discriminations in consumer perceptions of both the positive and negative roles of price appear plausible. Previous studies addressed relationships between price perception on customers' attitudes and behaviors in the online environment. Studies found that perceived cost is strictly linked to consumers' attitude toward the use of a new technology (Choe, Park, Chung, and Moon, 2009; Du, Whinston, Lu, and Liu, 2010; cited in Pantano and Pierto, 2012). Previous studies also investigated price sensitivity (Han, Gipta, and Lehmann, 2001; Chu, Chintagunta, and Cebollada, 2008) and price dispersion on the Internet (Pan, Ratchford, and Venkatesh, 2004). Customers in the online environment seem to be more sensitive concerning price because of the availability of price comparison sites that allow easy comparison of prices without fees. Online customers are sensitive to price for other reasons, such as delivery fees, which have become negative factors in intention to shop online, and transaction fees that depend on the market situation. Overall customers' price perceptions in the online environment are lowered by such effects as price comparison sites and efficient management of supply chain. Therefore, customers' expectations concerning price are being lowered in the online environment but are also based on how they perceive websites are useful. Therefore, it was hypothesized that perceived lower price in the online environment affects perceived usefulness.

H2: Perceived lower price online has a positive effect on perceived usefulness.

\subsubsection{Effects Of Convenience Perception On Perceived Usefulness}

The concept of convenience first appeared in marketing literature through Copeland's (1923) classification of goods and overtime. The use of the word convenience changed from a descriptor of products into its own unique concept with an emphasis on time buying or time savings (Yale and Venkatesh, 1986, cited in Beauchamp and Ponder, 2010). Johnson and Barbara (2002) indicated convenience appears to be a factor unique to the Internet because of its interactive and transactional abilities. Uses and gratifications and expectancy value researchers have identified convenience as a significant motivation for Internet use (Barbara and Johnson, 2001, cited in Johnson and Barbara, 2002).

Online stores make huge efforts to provide the best shopping experience by encompassing the most important and complex functionalities while delivering them in an easy and user-friendly way. Thus, the 
convenience of online shopping makes it possible to save time, avoid crowded markets, solve parking problems, and access online stores 24 hours a day, 7 days a week, without stress and the need to carry heavy items. In fact, the top reason (69\%) for shopping online, based on a poll conducted by The Nielsen Company (www.nielsen.com), was, "when I buy online, I can shop whenever I'd like." The second most cited reason (57\%) was that online shopping "allows me to avoid the holiday shopping crowds at stores." For these reasons, consumers across the globe are increasingly exchanging the experience of shopping in traditional crowded markets for one-click convenience as online shopping becomes a safe and popular option. The Nielsen Company (www.nielsen.com) polled 26,312 participants from 48 markets: Europe, Asia Pacific, the Americas and the Middle East. According to this Global Nielsen Consumer Report, over 85 percent of the world's online population has used the Internet to make a purchase, up 40\% (875 million) from two years previously (627 million), and more than half of Internet users were regular online shoppers, making online purchases at least once a month. Therefore, the convenience factor is expected to have a strong influence on online consumers' perceived usefulness of Web stores and their intention to shop online. Thus, it is hypothesized that perceived convenience in the online environment affects perceived usefulness.

H3: Perceived convenience provided online has a positive effect on perceived usefulness.

\subsubsection{Effects Of Perceived Product And Service Quality On Perceived Usefulness}

Perceived quality could be defined as the consumer's judgment about a product's overall excellence or superiority (Zeithaml, 1988, cited in Bei and Chiao, 2001). Previous studies discussed perceived product and service quality in terms of a continuum (Rathmell, 1966) by establishing relationships to satisfaction and loyalty (Bei and Chiao, 2001). Etzion and Pang (2014) stated that online services differ from traditional services because they promote relationship-building and interactivity among users and thus exhibit positive network effects. Referring to service, Holbrook (1994) stated, because "service excellence operates as an ideal, a standard against which judgments are ultimately formed," delivering promises and performing functions will lead to positive perception regarding the "usefulness" of online shopping and its service quality. In the online environment, perceived product and service quality is also based on reviews that affect attitudes about product and service quality or purchase decisions (Jensen, Averbeck, Zhang, and Wright, 2013). Thus, it is hypothesized that perceived product and service quality in the online environment affects perceived usefulness.

H4: Perceived product and service quality provided online has a positive effect on perceived usefulness.

\subsection{Effects On Perceived Ease Of Use}

Perceived ease of use is defined as the individual's perception that using the new technology will be free of effort (Davis, 1989, 1993). Applying this context to that of online shopping, ease of use refers to consumers' perceptions that shopping on the Internet will involve a minimum of effort (Davis, 1989, 1993). Whereas perceived usefulness refers to consumers' perceptions regarding the outcome of the online shopping experience, perceived ease of use refers to their perceptions regarding the process leading to the final online shopping outcome (Monsuwe, Dellaert, and Ruyter, 2004). In short, perceived usefulness is how effective shopping on the Internet is in helping consumers accomplish their tasks and perceived ease of use is how easy the Internet is to use as a shopping medium (Monsuwe, Dellaert, and Ruyter, 2004). According to the TAM, perceived ease of use has a dual effect, direct as well as indirect, on consumers' intention to shop online. The indirect effect on intention occurs through perceived usefulness because the easier a technology is to use, the more useful it can be (Venkatesh, 2000; Dabholkar, 1996; Davis, Bagozzi, and Warshaw, 1989).

\subsubsection{Effects Of Convenience Perception On Perceived Ease Of Use}

As discussed, convenience has been a key factor affecting customers' attitudes and behaviors in the online environment. Jiang, Zhilin, and Jun (2013) stated that the convenience dimension of online shopping has been one of the principal motivations behind customers' inclinations to adopt online shopping. Seiders, Berry, and Gresham (2000) proposed that dimensions of retail shopping convenience include access, search, transaction, and possession, all of which involve concepts of the speed and ease with which consumers can reach or engage a retailer, identify 
and select products, amend transactions, and obtain desired products. Based on these considerations, it is hypothesized that perceived convenience in the online environment also affects perceived ease of use.

H5: Perceived convenience provided online has a positive effect on perceived ease of use.

\subsubsection{Effects Of Perceived Product And Service Quality On Perceived Ease Of Use}

Previous studies indicated that perceived product quality played a crucial role in purchasing choices (Brucks, Zeithaml, and Naylor, 2000, cited in Bei and Chiao, 2001). Previous studies also discussed service quality as a key construct in measuring consumer satisfaction and loyalty (Parasuraman, Zeithaml, and Berry, 1985; Bei and Chiao, 2001). Product and service quality in the online environment is difficult to assess (Figueiredo 2000) because of the virtualized space. Customers in the online environment rely on reviews (Jensen, Averbeck, Zhang, and Wright, 2013) and word of mouth (Shen, Li, and DeMoss, 2012) to predict perceived product and service. How easily perceived product and service quality can be determined by the Web influences ease of use and purchase intention. Therefore, it is hypothesized that perceived product and service quality in the online environment affect perceived ease of use.

H6: Perceived product and service quality online have a positive effect on perceived ease of use.

\subsubsection{Effects Of Perceived Desire To Shop Without A Salesperson On Perceived Ease Of Use}

One of the factors contributing to dissatisfaction with e-businesses in the computer-mediated environment is the lack of a physical salesperson. To resolve the complaint of a lack of a salesperson, online businesses develop the tools that address that limitation, such as lists of frequently asked questions with a filtering system and online chatting service; however, these do not seem to be widely used by customers and are not actively operated by ebusinesses. Therefore, this limitation might become a major complaint, particularly for inexperienced Internet users, customers who are willing to purchase products that require physically touching, smelling, seeing, or hearing the products, and customers who prefer to receive a salesperson's guidance. Despite concerns about the lack of a salesperson online, customers' decision-making might not rely on a salesperson. Online customers might prefer to order products online either because they do not prefer a salesperson's interference because they think online stores might provide more objective and detailed information. Previous studies discussed the role of salespersons and task characteristics, such as skill variety, task identity, task significance, and feedback (Teas, 1982). Consumers might prefer to read product specifications from Web pages rather than to listen to a salesperson. Based on this consideration, it is hypothesized that perceived desire to shop online without a salesperson positively affects perceived ease of use.

H7: Perceived desire to shop online without a salesperson has a positive effect on perceived ease of use.

\subsection{Effects Of Perceived Usefulness, Perceived Ease Of Use, And Purchase Intention}

Thus far, it has been hypothesized that perceived ease of use affects perceived usefulness and purchase intention, which has been studied in terms of why a consumer purchases a particular brand (Shah, Aziz, Jaffari, Waris, and Ejaz, 2012). Purchase intention has been identified as the consequences of various factors, such as attitude (Fishbein and Ajzen, 1975) and predictor of satisfaction (Taylor and Baker, 1994; Oliver, 1980). Thus, it is hypothesized that both perceived usefulness and ease of use affect purchase intention.

H8: Perceived ease of use has a positive effect on perceived usefulness.

H9: Perceived usefulness in the online environment has a positive effect on purchase intention.

H10: Perceived ease of use in the online environment has a positive effect on purchase intention. 


\subsection{Effects Of Trust On Purchase Intention}

One of the most frequently cited reasons for consumers not shopping on the Internet is the lack of trust (Lee $\&$ Turban, 2001) and a level of risk. Researchers found that people rely on their general disposition to trust when in a novel situation (Rotter, 1971). According to Doney and Cannon (1997), the most salient source of trust in a retail setting is the salesperson with the consumer trust being dependent on the salesperson's expertise, likeability, and similarity to the customer. However, in the online environment, the role of physical salesperson is replaced by help buttons and search features, thus removing the basis of consumer trust in the shopping experience (Lohse \& Spiller, 1998). Consumers cannot physically check the quality of a product or monitor the safety and security of sending sensitive personal and financial information while shopping on the Internet (Lee \& Turban, 2001). This study suggests that consumers' trust in online stores has a positive effect on perceived usefulness. Hallegatte and Nantel (2006) confirmed that the non-technological related construct of trust on a website affects the intention to visit a commercial website again. Consequently, it is hypothesized that lack of trust in the online environment negatively affects purchase intention.

H11: Lack of trust in the online environment has a negative effect on purchase intention.

\section{METHODOLOGY}

Data for this study were collected using email, a survey website, and offline. Because the research addressed online shopping intentions, the target population included both customers who had online shopping experience and those who had possibly used the Internet for seeking product characteristics and detailed information. This study considered a relatively younger age group for the respondents because people in such an age group tend to be more interested in using new technologies to find new products, search for product information, and compare and evaluate alternatives (Wood, 2002). To reach the target population and valid participants, the survey document and the link to the online survey were sent deliberately to people in the email contact list. Thus, only users who fit the target group were requested to answer the questionnaire. Having answered via email, each respondent was limited with a single chance to fill out the survey. When respondents answered the questions on the online survey website, client-side cookie tracking and server-side session control were implemented. In addition, no incentives were provided to further decrease the likelihood of duplicate responses. Thus, the problem of multiple responses from the same respondent was eliminated.

\subsection{Pilot Test}

To develop a meaningful set of survey questions, a pilot test was conducted with a small group of fourteen respondents; then, based on the obtained results, the current and more comprehensive survey with meaningful questions was developed. The pilot test consisted of two parts - qualitative and quantitative. First, it was necessary to conduct qualitative research in the form of in-depth interviews. The responses from the in-depth interviews were supposed to form a clear foundation for further mass quantitative survey and reveal practically applicable and essential factors that influence consumers' behavioral intentions to shop online. To validate the model, the quantitative survey was administered to the same target respondents to check consistency. The data were collected via email. The descriptive data of the pilot test survey asked respondents whether they felt they needed an online shopping website. Seventy percent responded with yes or absolutely yes. The statistical data indicated that perceived usefulness and availability of detailed information had considerable effect on behavioral intention, with the latter being stronger. The effect of wide product selection was smaller but still statistically significant. According to the pilot test, the need for a salesperson's help was expected to have a significant effect on behavioral intention of consumers to shop online.

\subsection{Main Study}

This study used a 7-point scale for respondents' opinions, ranging from 1 (strongly disagree) to 7 (strongly agree). Two hundred sixteen responses were unique and valid, with a response rate of $80 \%$. Descriptive statistics indicate that respondents were almost equally dispersed according to gender. According to the descriptive statistics gathered as a result of this survey, $76.39 \%$ had bachelor degrees or were currently pursuing such degrees, and $21.76 \%$ possessed a master's degree or were studying in the master's programs. Socioeconomically the subjects 
were divided into two major groups, those who are students $(61.57 \%)$, and those who work as middle level employees (28.24\%), indicating they were recent graduates. Most respondents (93.52\%) considered themselves intermediate $(29.17 \%)$, upper-intermediate $(32.87 \%)$, or advanced $(31.48 \%)$ online users. A very high percentage $(90.28 \%)$ of the respondents accessed the Web daily $(63.43 \%)$ or at least several times a week $(26.85 \%)$. They accessed the Internet from home $(53.70 \%)$, school $(37.50 \%)$, the office $(36.57 \%)$ or Internet shops $(45.83 \%)$, or through their mobile phones (3.24\%). When subjects with online shopping experience were asked how satisfied they were with such experiences, $11.92 \%$ indicated dissatisfaction. At the same time, among the total number of respondents in this survey, most $(79.63 \%)$ were quite satisfied with their offline shopping.

\section{RESULTS}

The results of the construct reliability test, which includes Cronbach's alpha and a convergent validity test (principal component analysis with Varimax rotation and Kaiser normalization), are shown in Table 1. The alpha coefficients of perceived usefulness (PU), perceived ease of use (PEOU), lack of trust (TRUST), price perception (PRICE), perceived product information (INFO), perceived product and service quality (SERV), and convenience perception (CONV) are higher than 0.7 , which is considered "acceptable." These results indicate the items have relatively high internal consistency. Moreover, the factor loadings of above 0.5 are considered practically significant (Hair, 1998). Cronbach's alpha coefficients do not exceed 0.95, indicating items are not redundant. The construct and convergent validity measures of the variable, perceived desire to shop without a salesperson (DESIRE) are relatively low, but according to previous studies, modest reliability of .60 or .50 will suffice (Nunnally, 1978).

Table 1: Reliability And Convergent Validity Of Construct

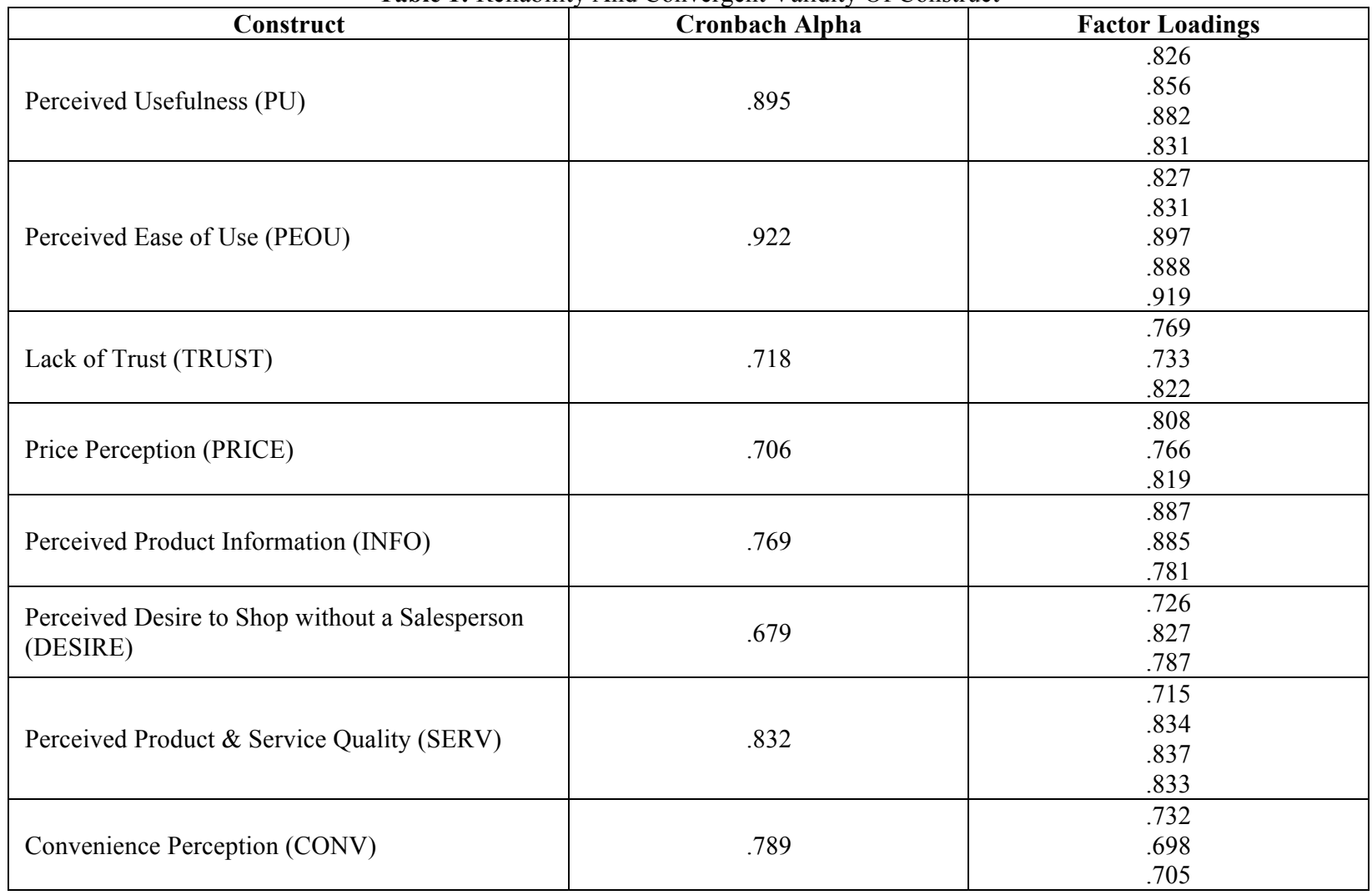

Further, the research model was tested with structural equation modeling. As shown in Table 2, perceived product information, price perception, convenience perception, and perceived service and product quality all had statistically significant positive effects on perceived usefulness. Therefore, hypotheses 1 4 were accepted. Convenience perception, perceived service and product quality, and perceived desire to shop without a salesperson had a statistically significant positive effect on perceived ease of use. Therefore, hypotheses $5 \sim 7$ were also accepted. 
Table 2: Effects Of Factors On Perceived Usefulness And Ease Of Use

\begin{tabular}{|l|c|c|c|c|l|}
\hline & $\boldsymbol{B}$ & $\boldsymbol{S} \boldsymbol{B}$ & $\boldsymbol{B e t a}$ & $\boldsymbol{t}$ & \\
\hline PRICE & .217 & .050 & .217 & $4.298^{* * *}$ & Perceive usefulness \\
\hline INFO & .076 & .046 & .076 & $1.663^{*}$ & $\mathrm{R}^{2}=.632$ \\
\hline SERV & .281 & .054 & .281 & $5.175^{* * *}$ & \\
\hline CONV & .259 & .051 & .259 & $5.127^{* * *}$ & \\
\hline & & & & & \\
\hline DESIRE & .113 & .060 & .113 & $1.898^{*}$ & Perceived ease of use \\
\hline SERV & .345 & .066 & .345 & $5.246^{* * *}$ & $\mathrm{R}^{2}=.356$ \\
\hline CONV & .297 & .062 & .297 & $4.801^{* * *}$ & \\
\hline
\end{tabular}

Note. PRICE = price perception; INFO = perceived product and service information; SERV = service \& product quality; CONV $=$ convenience of online shopping; DESIRE $=$ perceived desire to shop without a salesperson;

${ }^{* * *} p=<.001 .{ }^{* *} p=<.005 .{ }^{*} p=<.05$.

As shown in Table 3, this study also found that effects of perceived ease of use on perceived usefulness (H8) was accepted at alpha 0.001. As hypothesized, perceived usefulness and perceived ease of use had a statistically significant positive effect on behavioral intention to shop online (H9 and 10: see Table 4). Finally, lack of trust had a significant negative effect on purchase intention to shop online (H11: see Table 5).

Table 3: Effects Of Perceived Ease Of Use On Perceived Usefulness

\begin{tabular}{|l|c|c|c|c|l|}
\hline & $\boldsymbol{B}$ & $\boldsymbol{S E}$ & $\boldsymbol{B e t a}$ & $\boldsymbol{t}$ & \\
\hline PEOU & .620 & .054 & .620 & $11.562^{* * *}$ & Perceive Usefulness \\
\hline \multicolumn{2}{|l}{} & & & & $\mathrm{R}^{2}=.385$ \\
\hline
\end{tabular}

Note. PEOU $=$ Perceived Ease of Use

${ }^{* *} p=<.001$.

Table 4: Effects Of Perceived Usefulness And Ease Of Use On Purchase Intention

\begin{tabular}{|l|c|c|c|c|l|}
\hline & $\boldsymbol{B}$ & $\boldsymbol{S E}$ & $\boldsymbol{B e t a}$ & $\boldsymbol{t}$ & \\
\hline PEOU & .325 & .146 & .179 & $2.231^{*}$ & Intention to shop online \\
\hline PU & .470 & .146 & .258 & $3.218^{* * *}$ & $\mathrm{R}^{2}=.156$ \\
\hline
\end{tabular}

Note. PEOU $=$ Perceived Ease of Use; PU $=$ Perceived Usefulness

${ }^{* * *} p=<.001 .{ }^{*} p=<.05$.

Table 5: Effects Of Trust On Purchase Intention

\begin{tabular}{|l|c|c|c|c|l|}
\hline & $\boldsymbol{B}$ & $\boldsymbol{S E}$ & $\boldsymbol{B e t a}$ & $\boldsymbol{t}$ & \\
\hline TRUST & -.355 & .122 & -.195 & $-2.915^{* *}$ & Intention to shop online \\
\hline & & & & & $\mathrm{R}^{2}=.038$ \\
\hline
\end{tabular}

Note. TRUST $=$ trust

${ }^{* * *} p=<.005$

\section{CONCLUSION}

The purpose of this study was to investigate i) the effects of such factors as product information, price, convenience, and perceived product or service quality on perceived usefulness; ii) the effects of convenience, perceived product or service quality, and desire to shop without a salesperson on perceived ease of use; iii) the effects of perceived ease of use on perceived usefulness; iv) the effects of perceived ease of use and usefulness on intentions to shop online; and v) the effects of trust on purchase intentions. This study found that proposed factors affecting perceived usefulness and ease of use are significant. Among the results, this study also found that consumers' perceived ease of use of online stores is positively related to their intention to shop online. This finding supports prior research which was based on offline shopping environment (Arnold, 1977) indicating that ease of navigation through the online store and a fast checkout process are important factors in attracting customers to shop online. Perceived usefulness also had a statistically significant effect on customers' behavioral intention to shop online. Lack of trust, as mentioned by numerous researchers, had a statistically significant negative effect on intention to shop online. The present study shows that perceived usefulness had slightly greater effect on consumers' purchase intention to shop online than did perceived ease of use, a finding similar to those of most TAM studies. Lack of trust was one of the major constructs in this research model that negatively affected buyers' intentions to 
purchase products online. Because lack of trust had a statistically significant negative effect on purchase intention, various trust-building factors should be considered when designing and developing online shopping stores. This study indicated that to build trust in their online stores, businesses should leverage the established brands and thirdparty trust marks. The results of the study also find that price perception significantly affects perceived usefulness. If online stores sell products with lower prices than brick-and-mortar stores, people are likely to perceive online stores as useful. Companies should also note that customers who intend to shop online rely on detailed product information due to reasons such as computer-mediated environment where customers cannot easily judge the quality of the products (Figueiredo, 2000). More applications of advanced systems, such as customized recommender and collaborative filtering, will help enhance usefulness and ease of use.

This study had limitations. This study did not consider other important aspects of consumer behavior such as prior online shopping experience, social impact, and risk and enjoyment factors. Further research needs to address these constructs. Further research should also consider a larger sample size to increase reliability. The results of this study have the following implications. First, research findings indicate potential customers' acceptance levels of online shopping, whether they are ready for the adoption of changed lifestyle and, if not, what encourages and discourages them from shopping on the Internet. Second, necessary strategies for businesses to implement are proposed, along with approaches they can use to enhance online environment. Third, these findings can predict behavioral intentions of consumers in the market environment, even where the concept of e-commerce is not mature yet. Last, this study serves as a basis for further research on e-commerce by providing further applications through adopting advanced technologies for increased levels of attitudes, behaviors, and satisfaction. The study could expand to the less developed areas of research, such as in the public sector and in developing countries. E-business models should also be integrated in further issues (Chhabra and Kumar, 2009), such as customer relationship management by applying new models based on advanced technology.

\section{AUTHOR INFORMATION}

Professor Cho is a professor at the KDI School of Public Policy and Management in Seoul, Korea. She published research papers in the various academic journals such as Journal of Business Research (JBR), Advances in Consumer Research (ACR), Journal of Business \& Economics Research (JBER), etc. E-mail: ycho@kdischool.ac.kr. (Corresponding author).

Esen Sagynov received a Master's degree from the KDI School of Public Policy and Management. He is currently working at Naver Corporation. E-mail: kadishmal@gmail.com.

\section{REFERENCES}

1. $\quad 17$ U.S.C.S. $\$ 512(\mathrm{c})(1)(\mathrm{A})-(\mathrm{C}) .(1998$, October 28).

2. 3 Systems Announces Filing of Patent Infringement Suit Against Formlabs and Kickstarter. (2012, November 20). Retrieved May 2, 2014, from Nasdaq GlobeNewswire: http://globenewswire.com/newsrelease/2012/11/20/506562/10013332/en/3D-Systems-Announces-Filing-of-Patent-Infringement-SuitAgainst-Formlabs-and-Kickstarter.html

3. 3 S Systems Unveils Next-Gen Popular Cube Consumer 3D Printer. (2013, January 7). Retrieved November 26, 2013, from 3DSystems: http://www.3dsystems.com/press-releases/3d-systems-unveils-nextgen-popular-cube-consumer-3d-printer

4. A Brief History of 3D Printing. (2014). Retrieved February 26, 2014, from T.RowePrice: http://individual.troweprice.com/staticFiles/Retail/Shared/PDFs/3D_Printing_Infographic_FINAL.pdf

5. Adams, D. A. (1992). Perceived Usefulness, Ease of Use, and Usage of Information. MIS Quarterly, 16 (2), 227-248.

6. Agarwal, R., \& Jayesh, P. (1999). Are Individual Differences Germande to the Acceptance of New Information Technologies? Decision Sciences , 30 (2), 361-391.

7. Aidarkulov, М. К. (2007 йил 13-June). Internet in Kyrgyzstan: Today and Tomorrow. Retrieved 2009 йил 10-October from Kyrgyz National Information Agency: http://kabar.kg/internetconference/index.php?vop=30 
8. Ajzen, I., \& Fishbein, M. (1980). Understanding Attitudes and Predicting Social Behavior. Englewood Cliffs, NJ: Prentice-Hall.

9. Amazon.com's Europeam Distribution Strategy, 9-605-002 (Harward Business School 2005 йил 30-June).

10. Arnold, S. J. (1977). A Comparative Analysis of Determinant Attributes in Retail Store Selection. Advances in Consumer Research (5), pp. 663-667.

11. Aro Mfg. Co. v. Convertible Top Replacement Co., 377 U.S. 476 (1964).

12. Babin, B. J., Darden, W. R., \& Griffin, M. (1994). Work and/or Fun: Measuring Hedonic and Utilitarian Shopping Value. Journal of Consumer Research, 20, 644-656.

13. Banwatt, P. (2013, February 20). (Paul's) Post One, Part One: Patents and 3D Printing . Retrieved February 26, 2014, from Law in the Making The 3D Printing Law Blog ::: Patents, Copyrights, Trademarks and Novel Issues: http://lawitm.com/post-one-part-one-patents-and-3d-printing/

14. Baroudi, J. J., Olson, M. H., Ives, B., \& Davis, G. B. (1986). An Empirical Study of the Impact of User Involvement on System Usage and Information Satisfaction. Communications of the ACM , 29 (3), 232238.

15. Barr, A. (2013, December 2). Amazon testing delivery by drone, CEO Bezos says. Retrieved April 22, 2014, from USA Today: http://www.usatoday.com/story/tech/2013/12/01/amazon-bezos-dronedelivery/3799021/

16. Beaman, J. J., Darrah, J. F., \& Deckard, C. R. (1986). Patent No. US 5155324 A. United States.

17. Bradshaw, S., Bowyer, A., \& Haufe, P. (2010). The intellectual property implications of low-cost 3D printing. ScriptEd , 7 (1), 5-31.

18. Burns Alvin C., B. R. (2009). Marketing Research (6th ed. ed.). Upper Saddle River, NJ: Prentice Hall.

19. Charles Q. Choi, C. Q., \& Txchnologist. (2013, December 19). Loudspeaker Is First Complete 3D-Printed Consumer Electronic. Retrieved March 6, 2014, from Scientific American:

http://www.scientificamerican.com/article/loudspeaker-is-first-complete-3d-printed-consumer-electronic/

20. Chavez, E., Molitch-Hou, M., Horne, R., Park, R., Sher, D., \& Taylor, S. (2014, March). Category Archives: Materials. Retrieved March 15, 2014, from 3D Printing Industry: http://3dprintingindustry.com/raw-materials/

21. Chen, L., Gillenson, M. L., \& Sherrel, D. L. (2002). Enticing online consumers: an expended technology acceptance perspective. Infomation \& Management , 39 (8), 705-719.

22. Childers, T. L., Carr, C. L., Peck, J., \& Carson, S. (2001). Hedonic and utilitarian motivations for online retail shopping behavior. Journal of Retailing , 77, 511-535.

23. Choo, C. W., \& Bontis, N. (2002). The strategic management of intellectual capital and organizational knowledge. New York: Oxford University Press US.

24. Civil Initiative on Internet Policy in Kyrgyzstan. (2009 йил 1-May). Survey of Internet Audience in Kyrgyzstan. Retrieved 2009 йил 10-July from Civil Initiative on Internet Policy: http://www.internetpolicy.kg/en/node/306

25. Cochrane, L. (2014, July 17). 3D Printed Parts to the Rescue: Please share your stories. Retrieved March 15, 2014, from Make:: http://makezine.com/2013/07/17/3d-printed-parts-to-the-rescue-please-share-yourstories/

26. Crump, S. S. (1992). Patent No. US5121329 A. United States.

27. Dabholkar, P. A. (1996). Consumer evaluations of new technology-based self-service options: An investigation of alternative models of service quality. International Journal of Research in Marketing , 13 (1), 29-51.

28. Davis, F. D. (1989). Perceived usefulness, perceived ease of use, and user acceptance of information technology. MIS Quarterly, 13 (3), 319-340.

29. Davis, F. D. (1993). User acceptance of information technology: system characteristics, user perceptions and behavioral impacts. International Journla of Man-Machine Studies , 38 (3), 475-487.

30. Davis, F. D., Bagozzi, R. P., \& Warshaw, P. R. (1989b). User Acceptance of Computer Technology: A Comparison of Two Theoretical Models. Management Science, 35 (8), 982-1003.

31. Dayal, G. (2012, October 01). Synth manufacturer lets customers 3D print their own parts. Retrieved February 27, 2014, from Wired.CO.UK: http://www.wired.co.uk/news/archive/2012-10/01/3d-print-synthparts

32. de Jong, J. P., \& de Bruijn, E. (2013, Winter). Innovation Lessons From 3-D Printing. MIT Sloan Management Review , 43-52. 
33. Dimitrov, D., Schreve, D., \& DeBeer, N. (2006). Advances in three dimensional printing-state of the art and future perspectives. Rapid Prototyping Journal , 12 (3), 136-147.

34. Doney, P. M., \& Cannon, J. P. (1997). An Examination of the Nature of Trust in Buyer-Seller Relationships. Journal of Marketing , 61 (2), 35-51.

35. Drumm, B. (2011, December 17). Printrbot: Your First 3D Printer . Retrieved November 26, 2013, from Kickstarter: https://www.kickstarter.com/projects/printrbot/printrbot-your-first-3d-printer

36. Dyson DC25 Repair by 3D Scanning, GeoMagic Fix and 3D Printing a replacement Tool Catch. (2012, December 13). Retrieved March 15, 2014, from Parts2Print: http://www.parts2print.com.au/blog/DysonToolCatch_3DScan_3DPrinting

37. Ecker, J. (2011, March 3). RepRap: The Self Replicating DIY $\overline{3 D}$ Printer in Your Home. Retrieved May 9 , 2014, from kickstarter: https://www.kickstarter.com/projects/johnecker/reprap-diy-3d-printing-in-yourhome

38. Fishbein, M., \& Ajzen, I. (1975). Belief, Attitude, Intention and Behavior. MA: Addison-Wesley.

39. Flaherty, J. (2012, November 21). 3D Systems Sues Formlabs and Kickstarter for Patent Infringement. Retrieved May 13, 2014, from Wired: http://www.wired.com/2012/11/3d-systems-formlabs-lawsuit/

40. Formlabs Announces \$19 Million Series A Round to Disrupt 3D Printing. (2013, October 24). Retrieved May 13, 2014, from Formlabs: http://formlabs.com/company/press/formlabs-series-a-fundingannouncement/

41. Frey, T. (n.d.). 2050 and the Future of Transportation. Retrieved April 22, 2014, from Davinci Institute: http://www.davinciinstitute.com/papers/2050-and-the-future-of-transportation/

42. $\quad$ Gartner Newsroom. (2013, October 08). Retrieved January 24, 2014, from Gartner: http://www.gartner.com/newsroom/id/2603623

43. Gefen, D., \& Detmar, S. (1997). Gender Difference in Perception and Adoption of E-Mail: An Extension to the Technology Acceptance Model. MIS Quarterly, 21 (4), 389-400.

44. George, D. \&. (2003). SPSS for Windows step by step: A simple guide and reference. (4th ed. ed.). Boston: Allyn \& Bacon.

45. Giller, E., Azzolino, F., \& Davidson, T. (2012). 3D Printing: Opportunities and Chanllenges. IQT Quarterly, 4 (2), 9-13.

46. Global-Tech Appliances, Inc., et al., v. SEBS S.A., 131 S. Ct. 2060 (2011).

47. Hair, J. J. (1998). Multivariate Data Analysis (5th Edition ed.). Upper Saddle River, NJ: Prentice Hall.

48. Hallegatte, D., \& Nantel, J. (2006 йил 1-February). The Interwined Effect of Perceived Usefulness, perceived ease of use and trust in a website on the intention to return. Retrieved 2009 йил 29-October from RBC Financial Group Chair of Electronic Commerce:

http://www.chairerbc.com/chairerbc/fr/publications.asp

49. Hansell, S. (2007, May 7). Beam It Down From the Web, Scotty. The New York Times , pp. 1-4.

50. Hirschman, E. C., \& Holbrook, M. B. (1982). Hedonic consumption: emerning concepts, methods and propositions. Journal of Marketing , 46 (3), 92-101.

51. Holbrook, M. B. (1994). The nature of customer value: an axiology of services in the consumption experience. In R. T. Rust, \& R. L. Oliver, Service Quality: New Directions in Theory and Practice (pp. 2171). Newbury Park, CA: Sage.

52. Horrigan, J. В. (2008 йил 13-February). Online Shopping. Retrieved 2009 йил 10-October from PEW Internet \& American Life Project: http://www.pewinternet.org/Reports/2008/Online-Shopping.aspx

53. Hull, C. (1984). Patent No. US4575330 A. United States of America.

54. Intellectual Property Policy. (n.d.). Retrieved January 20, 2014, from MakerBot Thingiverse: http://www.thingiverse.com/legal/ip-policy

55. Järveläinen, J. (2007). Online Purchase Intentions: An Empirical Testing of a Multiple-Theory Model. Journal of Organizationsl Computing and Electronic Commerce , 17 (1), 53-74.

56. Jepson, B. (2007, June 6). Reprap Research Foundation: get yer Reprap parts here. Retrieved May 2, 2014, from Makezine: http://makezine.com/2007/06/06/reprap-research-foundatio/

57. Kau, A. K., Tang, Y. E., \& Ghose, S. (2003). Typology of online shoppers. Journal of Consumer Marketing , 20 (2), 139-156.

58. Khalifa, M., \& Limayem, M. (2003). Drivers of Internet shopping. Communications of the ACM , 46, 233239. 
59. Kraft, C. (2009, March 16). CupCake CNC kit. Retrieved November 26, 2013, from Hack A Day: http://hackaday.com/2009/03/16/cupcake-cnc-kit/

60. Leadership Online: Barnes \& Noble vs. Amazon.com (A), 9-798-063 (Harvard Business School 2004 йил 16-March).

61. Lederer, A. L., Maupin, D. J., Sena, M. P., \& Zhuang, Y. (2000). The technology acceptance model and the World Wide Web. Decision Support Systems , 29 (3), 269-282.

62. Lee, M. K., \& Turban, E. (2001). A Trust Model for Consumer Internet Shopping. International Journal of Electronic Commerce, $6(1), 75-91$.

63. Leno, J. (2009, June 8). Jay Leno's 3D Printer Replaces Rusty Old Parts. Retrieved March 15, 2014, from Popular Mechanics: http://www.popularmechanics.com/cars/jay-leno/technology/4320759

64. Lipson, H., \& Kurman, M. (2013). Fabricated: The new world of $3 D$ printing. John Wiley \& Sons.

65. Lohse, G. L., \& Spiller, P. (1998). Electronic Shopping. Communications of the ACM , 41 (7), 81-87.

66. Main Page. (2013, August 31). Retrieved February 27, 2014, from OpenMokoWiki: http://wiki.openmoko.org/wiki/Main_Page

67. MakerBot $\AA^{\circledR}$ Replicator ${ }^{\mathrm{TM}} 2$ Desktop 3 D Printer Sets New Standard. (2012, September 19). Retrieved

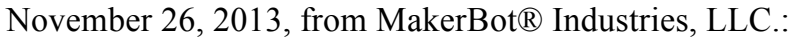
http://downloads.makerbot.com/replicator2/MakerBot_Replicator2_press_release.pdf

68. Marcoux, J., \& Bonin, K. R. (2012). Three Dimensional Printing: An Introduction for Information Professioinals. ICDS 2012, The Sixth International Conference on Digital Society (pp. 54-58). Valencia: Curran Associates, Inc.

69. Mathwick, C., Malhotra, N. K., \& Rigdon, E. (2002). The effect of dynamic retail experiences on experiential perceptions of value: an internet and catalog comparison. Journal of Retailing , 78 (1), 51-60.

70. Meet Our Alu Extruder. (2014). Retrieved November 26, 2013, from Printrbot: http://printrbot.com/

71. Menon, S., \& Kahn, B. (2002). Cross-category effects of induced arousal and pleasure on the Internet shopping experience. Journal of Retailing , 78, 31-40.

72. Metro-Goldwyn-Mayer Studios, Inc. et al. v. Grokster, Lted., et al. , 545 U.S. 913 (2005).

73. Mitchell, A. A., \& Olson, J. C. (1981). Are Product Attribute Beliefs the Only Mediator of Advertising Effects on Brand Attitude? Journal of Marketing Research , 18 (3), 318-332.

74. Monsuwe, T. P., Dellaert, B. G., \& Ruyter, K. d. (2004). What drives consumers to shop online? A literature review. International Journal of Service Industry Management, 15 (1), 102-121.

75. Moon, J.-W., \& Kim, Y.-G. (2001). Extending the TAM for a World-Wide-Web context. Information \& Management, 38 (4), 217-230.

76. NASA to launch 3-D printer into space to create tools abroad. (2013, October 1). Retrieved March 6, 2014, from NY Daily News: http://www.nydailynews.com/news/national/nasa-launch-3d-printer-space-article1.1472443

77. Nunnally, J. (1978). Psychometric theory (2nd ed. ed.). New York: McGraw Hill .

78. Online Grocery Retailing: Building the Last Mile to the Customer, IMD026 (International Institute for Management Development 2003 йил 20-March).

79. Pettis, B. (2012, January 9). Introducing The MakerBot Replicator ${ }^{\mathrm{TM}}$. Retrieved November 26, 2013, from MakerBot: http://www.makerbot.com/blog/2012/01/09/introducing-the-makerbot-replicator/

80. Pettis, B. (2012, September 24). Let's try that again. Retrieved May 2, 2014, from makerbot: http://www.makerbot.com/blog/2012/09/24/lets-try-that-again/

81. PolyJet Technology. (2014). Retrieved February 25, 2014, from Stratasys: http://www.stratasys.com/3dprinters/technology/polyjet-technology

82. Printrbot. (2014). Retrieved May 13, 2014, from Printrbot: http://printrbot.com/

83. ProCD, Inc. v. Zeidenberg, 86 F.3d 1447 (7th Cir. 1996).

84. RAF jets fly with $3 D$ printed parts. (2014, January 5). Retrieved February 27, 2014, from BBC News UK: http://www.bbc.com/news/uk-25613828

85. Replacement Parts. (2014). Retrieved February 27, 2014, from MakerBot Thingiverse: http://www.thingiverse.com/explore/newest/household/replacement-parts/

86. RepRap. (2013, October 13). Retrieved February 1, 2014, from RepRap.org: reprap.org

87. Robins Richard W., F. R. (Ed.). (2007). Handbook of Research Methods in Personality Psychology. New York, NY: The Guilford Press. 
88. (1991). Criteria for Scale Selection and Evaluation. In J. P. Robinson, P. R. Shaver, \& L. S. Wrightman, Measures of personality and social psychological attitudes (pp. 1-16). San Diego: Academic Press.

89. $\quad$ Ross, P. E. (2011, November 29). When Will We Have Unmanned Commercial Airliners? Retrieved April 22, 2014, from IEEE Spectrum: http://spectrum.ieee.org/aerospace/aviation/when-will-we-have-unmannedcommercial-airliners/0

90. Rotter, J. B. (1971). Generalized expectancies for interpersonal trust. American Psychologist , 26 (5), 443452.

91. Sayej, N. (2014, January 28). An Open-Source Community Wants to Fix Your Drone with 3D-Printed Parts. Retrieved March 8, 2014, from Motherboard: http://motherboard.vice.com/blog/an-open-sourcecommunity-wants-to-fix-your-drone-with-3d-printed-parts

92. Shapeways Content Policy and Notice Takedown Procedure. (2014). Retrieved January 14, 2014, from Shapeways.com: http://www.shapeways.com/legal/content_policy

93. Shim, J. P., Shin, Y. B., \& Nottingham, L. (2002). Retailer Web site influence on customer shopping: An exploratory study on key factors of customer satisfaction. Journal of the Association for Information Systems , 3 (3), 53-76.

94. Stemp-Morlock, G. (2010). Personal Fabrication. Communications of the ACM , 53 (10), 14-15.

95. Stratasys and MakerBot Complete Merger. (2013, August 15). Retrieved May 2, 2014, from Stratasys: http://investors.stratasys.com/releasedetail.cfm?ReleaseID=785515

96. Stratasys and Objet Complete Merger. (2012, December 3). Retrieved May 14, 2014, from Stratasys: http://investors.stratasys.com/releasedetail.cfm?ReleaseID=724378

97. Stratasys for a 3D World. (2014). Retrieved May 15, 2014, from Stratasys: http://www.stratasys.com/

98. Stratasys Gets Its Mojo With New 3D Printer. (2012, May 8). Retrieved November 26, 2013, from Stratasys: http://investors.stratasys.com/releasedetail.cfm?ReleaseID=671436

99. Stratasys, Inc. Announces initial Public Offering of 1.2 Million Shares of Common Stock. (1994, October 20). Retrieved May 2, 2014, from The Free Library: http://www.thefreelibrary.com/STRATASYS,+INC.+ANNOUNCES+INITIAL+PUBLIC+OFFERING+O F+1.2+MILLION...-

100. Stratasys, Inc. History. (n.d.). Retrieved November 2013, from FundingUniverse: http://www.fundinguniverse.com/company-histories/stratasys-inc-history/

101. Streiner, D. L. (2003). Starting at the beginning: an introduction to coefficient alpha and internal consistency. Journal of Personality Assessment, 80, 99-103.

102. The Nielsen Company. (2009). The Online Holiday Outlook: 2009 - What Consumers Have in Store for Retailers This Season. Nielsen Media Research.

103. The Nielsen Company. (2008). Trends in Online Shopping: a global Nielsen consumer report. Nielsen Media Research.

104. UCLA: Academic Technology Services. (2006). What does Cronbach's alpha mean? . (Statistical Consulting Group) Retrieved 08 07, 2012, from Introduction to SPSS: http://www.ats.ucla.edu/stat/spss/faq/alpha.html

105. Venkatesh, V. (2000). Determinants of perceived ease of use: integrating control, intrinsic motivation, and emotion into the technology acceptance model. Information Systems Research , 4 (4), 342-365.

106. Viacom Int'l, Inc. v. YouTube, Inc., 676 F.3d 19 (2012).

107. Vinodh, S., Sundararaj, G., Devadasan, S. R., Kuttalingam, D., \& Rajanayagam, D. (2009). Agility through rapid prototyping technology in a manufacturing environment using a 3D printer. Journal of Manufacturing Technology Management, 20 (7), 1023-1041.

108. Wilkie, W. L., \& Pessemier, E. A. (1973). Issues in Marketing's Use Of Multi-Attribute Attitude Models. Journal of Marketing Research , 10 (4), 429-441.

109. Wood, S. (2002). Future fantasies: a social change perspective of retailing in the 21 st century. Journal of Retailing , 78 (1), 77083.

110. Xiaoni Zhang, V. P. (2003). Factors Contributing to Purchase Intentions on the Internet. Journal of Internet Commerce, 2 (1), 14. 


\section{NOTES}

